\title{
School Success, Possible Selves, and Parent School Involvement*
}

\author{
Daphna Oyserman
}

\author{
Daniel Brickman
}

Marjorie Rhodes**

\begin{abstract}
Increased parent school involvement is associated with better academic outcomes; yet, proximal contributors to this effect remain understudied. We focus on one potential proximal contributor, youth's positive and negative future self-images or "possible selves," reasoning that if parent school involvement fosters possible selves, then interventions aimed at enhancing youths' possible selves should moderate the negative effect of low parent school involvement. We examine a 2-year follow-up of a randomized clinical trial of a possible self-based intervention $(N=239)$, demonstrating with regression equations that the intervention moderated the association of low parent school involvement with worse grades and less school-engaged behavior. Low parent school involvement negatively influenced achievement among control, not intervention youth, suggesting that school-based, possible self-focused interventions can moderate the undermining effect of low parent school involvement.
\end{abstract}

Key Words: achievement gap intervention, African American, high-risk youth, Latino, parent involvement, possible selves, school success.

Daily behaviors (e.g., doing homework, paying attention in class) become imbued with meaning when they are linked to the future, especially self-relevant goals for the future, such as graduating from high school or going to college. The term possible self has been coined to describe incorporation of future goals into the self-concept (Markus \& Nurius, 1986). Possible selves are positive and negative images of the self already in a future state- the "clever" self who passed the algebra test, the "healthy" self who lost weight, the "drop-out" self who failed to graduate from high school, the "offtrack" self who uses drugs or becomes pregnant (Oyserman, Bybee, \& Terry, 2006; Oyserman \& Markus, 1990a, 1990b). By providing concrete positive expected and negative to-be-avoided future images, possible selves personalize goals and connect current behaviors to future states. In this way, possible selves improve self-regulatory capacity (Cross \& Markus, 1994; Oyserman \&
Markus, 1990a, 1990b; Oyserman, Terry, \& Bybee, 2002) and make one's current situation feel meaningful (Cross \& Markus, 1991).

Succeeding in school is a central life task of adolescence, and school failure can seriously limit future possibilities (Morrison, Bachman, \& Connor, 2005; Orfield, 2004). Unfortunately, school failure is all too common among low-income youth, especially lowincome youth from racial-ethnic minority groups. This achievement gap calls for creative and sustained response. In the current paper, we focus on unpacking proximal contributors to one factor associated with school success-parent school involvement. Whereas parent school involvement is clearly associated with positive attainments (e.g., Grolnick \& Slowiaczek, 1994; Miedel \& Reynolds, 1999; Woolley \& Bowen, 2007; Woolley \& Grogan-Kaylor, 2006), as we will outline below, it is not clear how parent school involvement influences academic outcomes, limiting

\footnotetext{
*Funding and support for this study came from NIMH grant R01 MH 58299 (Oyserman, PI). D. B. and M. R. were supported by the Michigan Prevention Research Training Grant (NIH grant T32 MH63057-03, Oyserman, PI). We thank the schools, teachers, parents, and children who participated and shared their responses, Kathy Terry for parent involvement data collection, and Jim Klein for help obtaining school grade records.

**Daphna Oyserman is a Professor at the University of Michigan with appointments in the Department of Psychology, the School of Social Work, and the Institute for Social Research, 426 Thompson Avenue, University of Michigan, Ann Arbor, MI 48106-1248 (daphna.oyserman@umich.edu). Daniel Brickman is a doctoral student in Psychology at the University of Michigan, East Hall, 530 Church Street, Ann Arbor, MI 48109-1043 (dbrick@umich.edu). Marjorie Rhodes is a doctoral student in Psychology, University of Michigan, East Hall, 530 Church Street, Ann Arbor, MI 48109-1043 (rhodesma@umich.edu).
} 
efforts to reduce risk for children. In the current paper, we propose that parent school involvement improves school outcomes in part because it signals to youth that school success is a self-relevant and attainable possible self and that negative "offtrack" possible selves such as delinquent involvement or early pregnancy can be avoided through engagement with school. To the extent that at least some of the active ingredients of parent school involvement can be duplicated by possible self-focused school-based intervention, then risk for youth can be ameliorated.

Parent school involvement is consistently associated with higher grades, fewer absences and higher high school graduation rates (North Central Regional Educational Laboratory, 1995) across grades (Eccles \& Harold, 1996; Grolnick \& Slowiaczek, 1994; Hill, 2001; Hill et al., 2004), and racial and ethnic groups (e.g., Hrabowski, Maton, \& Greif, 1998; Marschall, 2006; Steinberg, Lamborn, Dornbusch, \& Darling, 1992). Additionally, parent school involvement may function as a mechanism through which other family resource characteristics, such as parental education, are associated with school success (Grolnick \& Slowiaczek; Hill \& Taylor, 2004). However, the process by which parent school involvement influences academic achievement remains unclear, making it difficult to target programs for parents or to design school-based alternatives to buffer youths whose parents cannot sustain high levels of school involvement.

Although it seems reasonable to assume that parents influence their children's possible selves, we could not find empirical literature describing parental influence on children's possible selves. The purpose of the present study was to examine the extent to which a school-based, possible self-focused intervention moderates the negative effects of low parent school involvement. In the next sections, we outline gaps in the parent school involvement literature and present a working process model of how parent school involvement might improve students' academic outcomes, focusing on how parent school involvement may influence youth's possible selves. Results have implications for targeting parent-focused programs and for school-based programs for youth.

\section{Parent School Involvement}

Not all parents are highly involved in their children's schools; generally, parent school involvement declines in adolescence and is lower among students more at risk of school underperformance (Eccles \& Harold, 1996). Low parent school involvement is also associated with economic and other factors (e.g., language barriers) that increase parents' stress and reduce parents' time and other resources (Baker \& Stevenson, 1986; Lareau, 1996; Reynolds, 1991). Targeting parent school involvement through direct interventions aiming to increase involvement remains a problematic solution to improving student academic outcomes for a number of reasons. First, in spite of program effort, parent participation is generally disappointingly low, making it difficult to interpret the effectiveness of parent training for lowincome families (Morrison et al., 2005). Reviews suggest that this problem of low participation holds both generally (Gross, Julion, \& Fogg, 2001; Hill \& Taylor, 2004; Morrison et al.) and in higher risk groups (e.g., Ialongo et al., 1999), as well as among parents who are low-income or minority group members, or both (e.g., Gross et al.).

Second, whereas parent school involvement itself involves very specific behaviors (e.g., attending school meetings), it is not entirely clear that simply increasing these behaviors will produce the desired effects. Even though research consistently demonstrates a main effect of parent school involvement behaviors on child achievement, this statistical association does not illuminate the process by which parent school involvement might produce better achievement. As parent school involvement is not operationalized in terms of behaviors like obtaining tutoring or doing homework with the child that might directly improve achievement, the positive influence of parent school involvement may be through the message it sends. By attending functions, activities, and meetings at school, schoolinvolved parents may signal their children that school matters for identity and that current effort in school is an investment in their future (see Grolnick \& Slowiaczek, 1994; Hill et al., 2004). In this way, parent school involvement may be associated with better school outcomes because of its more proximal effects on children's sense of who they can become. Indeed, parent school involvement often co-occurs with factors that also contribute to positive school outcomes such as parents' positive attitudes toward school (e.g., Marschall, 2006) and parental socioeconomic status, as well as with other parenting behaviors such as parenting efficacy (e.g., Machida, Taylor, \& Kim, 2002), parental monitoring, 
parental supervision, and parenting style (e.g., Bulcroft, Carmody, \& Bulcroft, 1998). Taken together, parent school involvement behaviors are likely to connect with children's belief that school is an important context to engage in efforts to attain positive and avoid negative possible selves.

This opens up possibilities for both thinking more broadly about parent school involvement and for thinking about interventions to reduce some of the negative effects of low parent school involvement. For example, a number of authors have suggested that children's involvement with school is related to social contextual factors that emphasize that doing well in school as a self-relevant future goal (e.g., for low-income minority youths; Connell, Spencer, \& Aber, 1994; Grolnick \& Slowiaczek, 1994). Consistent with this proposal, previous research indicates that parent school involvement is correlated with more focus on the future among children (e.g., McCabe \& Barnett, 2000) as well as with children's positive self-esteem (Marschall, 2006). Thinking about the future and feeling good about oneself may increase interest in and perceived efficacy to succeed in long-term projects like school success. More specifically, parent school involvement may provide youth with more salient schoolrelevant possible selves (Oyserman, 2007; Oyserman \& Fryberg, 2006).

\section{Possible Selves and Academic Outcomes}

\section{School-Focused Possible Selves}

School-focused possible selves describe expectations and concerns regarding one's school success and academic attainment, including images of oneself "passing" or avoiding "failing" as well as more global images such as "being smart." Having schoolfocused possible selves is positively correlated with endorsement of academic goals among European American (Anderman, Anderman, \& Griesinger, 1999) and African American (Oyserman, Gant, \& Ager, 1995) youth and with positive self-esteem among European American high school girls (Knox, Funk, Elliot, \& Bush, 1998). African American middle school boys and girls who have detailed and specific school-focused possible selves and strategies to attain them (e.g., go to class, ask the teacher for help) are more likely to do well in school than those who do not (Oyserman, Bybee, Terry, \& HartJohnson, 2004). Among African American and European American high school students, having school-focused possible selves is also associated with lower risk of involvement in delinquent activities (Oyserman \& Markus, 1990a, 1990b; Oyserman \& Saltz, 1993).

\section{Feared Offtrack Possible Selves}

Feared offtrack possible selves are possible selves focused on avoiding outcomes like becoming pregnant, hooked on drugs, or involved in crime that can have a derailing effect on school and other future possibilities. Having feared offtrack possible selves is associated with reduced school truancyabsenteeism among European American, Latino, and African American youth (Oyserman et al., 2006) and with lower risk of school dropout among Latino youth (Yowell, 2000, 2002). Particularly among parents and children living in low-income, high unemployment contexts, parent school involvement may provide children with both schoolfocused and feared offtrack possible selves coupled with the belief that engagement with school and effort in school will both increase chances of school success and reduce chances of becoming offtrack.

\section{The Present Study}

As outlined in the previous sections, we propose that parent school involvement positively influences academic attainment and that higher achieving children have more school focused and more feared offtrack possible selves. Our concern then is for children with less involved parents. We theorize that the lack of parent school involvement undermines school achievement and, given the positive connection between possible selves and academic success, also may serve as a context for the development of children who are both less focused on school and more "offtrack." We were interested in determining the extent to which an intervention that bolsters children's possible selves may in effect, buffer the negative impact of low parent school involvement.

Indeed, whereas much of the previously cited research linking possible selves to academic outcomes is correlational, experimental evidence supports a causal process whereby changing possible selves leads to change in academic behavior (e.g., 
Oyserman et al., 2002, 2006). In a randomized clinical trial (Oyserman et al., 2006), eighth graders were randomly assigned to receive their regularly assigned elective or to receive an 11-session possible selves based intervention called Adolescent Pathways: School-to-Jobs (STJ). The intervention was completed by the Thanksgiving break, prior to the conclusion of the first academic quarter. The authors reported moderate-sized direct effects on changing possible selves and linking possible selves with strategies. At the 2-year follow-up, intervention effects on academic outcomes were examined both at the end of ninth grade and at slopes of change over time. Effects included large effects on time spent doing homework and change in in-class disruptiveness, as well as small-to-moderate effects on school reported grades, slope of change in grades, unexcused absences, teacher reported in-class initiative taking, and slope of change in initiative taking and disruptiveness. The intervention also reduced 2year follow-up risk of depression (youth reported). Importantly, Oyserman et al. (2006) also demonstrated that the 2-year follow-up effects are mediated by change in possible selves and in the possible selfto-strategy linkage.

The current study builds on the evaluation described above, which demonstrates that the direct effect of the intervention on academic outcomes is mediated by the effect of the intervention on schoolfocused and feared offtrack possible selves (Oyserman et al., 2006). A full description of the intervention and its evaluation appears in Oyserman (2008). The current article tests the hypothesis that the possible self-based intervention moderates the effect of low parent school involvement, thus suggesting the importance of parent school involvement in creating and sustaining children's school-focused and feared offtrack possible selves. The 2-year follow-up (including available baseline academic controls) assessment data are used to test this moderation hypothesis by examining the extent that the intervention moderates the impact of parent school involvement on academic outcomes.

\section{Method}

\section{Sample and Procedure}

As detailed in Oyserman et al. (2006), to evaluate the efficacy of the intervention, the eighth grade cohort of three low-income Detroit middle schools was randomized into control and intervention groups in the fall of eighth grade (Mean age $=13$ years). Although the income of parents was not obtained, the student body on average could be termed low income in that two of three students received free or reduced lunch and students lived in census tracts averaging $54 \%$ of households below the poverty line, using data from the 2000 U.S. Census. This rate is well above the Census Bureau's $40 \%$ cutoff for describing a tract as a high poverty area (Bishaw, 2005).

Consistent effort resulted in a parental consent for child data collection rate of $94 \%$. Outcome analyses in the current paper controlled for baseline grades and in-class behavior and focused on the spring of ninth grade. Parent involvement data were obtained only once, in the first semester of ninth grade for 239 students (91\% of the total randomized sample; $n=131$ experimental, $n=108$ control; $n=127$ girls, $n=112$ boys; $n=179$ African American, $n=41$ Latino, and $n=19$ White) and did not significantly differ by condition, experimen$\mathrm{tal}=93 \%$ and control $=88 \%, \chi^{2}(1)=1.80, n s$.

Youth randomized to the control group attended their regularly scheduled elective; those randomized to STJ received STJ during that time slot over a 7week period in which 11 small group-based inschool sessions were presented twice weekly, followed by two parent-youth sessions. Fidelity to protocol was maintained via trained observer in vivo ratings and weekly staff meetings (Oyserman et al., 2006). For the in-school sessions, average attendance ranged from 80 to $90 \%$ by school (only 36 youths assigned to STJ failed to attend at least half the inschool sessions); for the parent-youth sessions, attendance was lower (40\%). Whether or not parents attended did not influence effects.

We used estimated data of Oyserman et al. (2006) and focus on the spring of ninth grade. Oyserman et al. (2006) reported both minimal attrition to that final data collection point and minimal missing data, with only four youth being completely lost to follow-up. Information from at least one source (youth, teacher, or school records) was obtained for $98.5 \%$ of the intention-to-treat (ITT) sample across the four measurement points; at any point in time, almost all school records $(92-96 \%)$ and teacher ratings $(83$ - 97\%) were obtained. Expectation maximization methods (Little \& Yau, 1998) were utilized to determine that approximately 
7.9\% of data across the four time-points and three data sources (youth, school, and teacher) were missing because of skipped items or unavailable information. According to Oyserman et al. (2006), although missingness was not completely random, Little's "missing completely at random" (MCAR) $\chi^{2}(d f=$ $16,115)=30,685.46 ; p<.001$, there was no evidence that it was not ignorable (Little \& Rubin, 2002). Most of the difference in ITT and compliant analyses sample size was because of suspension or expulsion within the first month of school; as a result, some youth were not in school to receive STJ.

\section{STJ Possible Selves Intervention}

Each session focused on developing an aspect of possible selves. Beginning session topics included linking school-focused possible selves to important social identities (e.g., gender or racial-ethnic groups), linking proximal possible selves to more distal adult possible selves, discussing how possible selves are influenced by role models, and linking present action to obtaining possible selves. Later sessions focused on identifying strategies that would help youth obtain their possible selves and coping with difficulty that they might encounter along their paths. Program activities involved individualized activities such as creating a timeline into one's future, active participation by students and group work. Once the youth sessions were completed, two final sessions included youth and parents with the goal of providing youth and parents structured activities to talk about possible selves and strategies to attain them.

\section{Measures}

Descriptive statistics and correlations among variables are presented in Tables 1 and 2 .

Parent school involvement. In the spring of ninth grade, parents rated their school involvement by phone $(85 \%)$ or by mail $(15 \%)$ on a 5 -item scale developed after examining how parent school involvement is typically operationalized and avoiding items that imply involvement because of child problems (e.g., going to school in response to school disciplinary action). In all, 239 parents were reached. Parent data were not estimated: Parents who were successfully contacted provided full responses, and estimating the involvement of noncontacted parents seemed imprudent. Parents were asked to respond yes or no to five questions: "Do you . ..." "attend parent/teacher conferences," "belong to or attend meetings of the parent-teacher organization," "talk with parents of the other children to plan and organize activities for [your child]," "belong to other school-based organizations with parents from [your child]'s school," and "act as a volunteer at the

Table 1. Parent School Involvement, School Performance at Waves 1 and 2 and Student Age: Descriptive Statistics and Correlations $(\mathrm{N}=207)$

\begin{tabular}{|c|c|c|c|c|c|c|}
\hline \multirow[b]{2}{*}{ Variables } & \multicolumn{3}{|c|}{ Wave 1} & \multicolumn{3}{|c|}{ Wave 2} \\
\hline & $\begin{array}{c}\text { Teacher-Rated } \\
\text { in-Class } \\
\text { Behavior }\end{array}$ & $\begin{array}{l}\text { Self-Reported } \\
\text { Grades }\end{array}$ & $\begin{array}{c}\text { Parent } \\
\text { Involvement }\end{array}$ & $\begin{array}{c}\text { Teacher-Rated } \\
\text { In-Class } \\
\text { Behavior }\end{array}$ & $\begin{array}{l}\text { School-Reported } \\
\text { Grade Point Average }\end{array}$ & Age \\
\hline $\begin{array}{l}\text { W1 teacher-rated } \\
\text { in-class behavior }\end{array}$ & - & & & & & \\
\hline W1 self-reported grades & $.22 * *$ & - & & & & \\
\hline W2 parent involvement & -.06 & .04 & - & & & \\
\hline $\begin{array}{l}\text { W2 teacher-rated } \\
\text { in-class behavior }\end{array}$ & $.31 * * *$ & $.23^{* *}$ & .07 & - & & \\
\hline W2 school-reported GPA & $.40 * * *$ & $.31 * * *$ & .08 & $.68 * * *$ & - & \\
\hline W1 age & -.01 & $-.19 * *$ & $-.20 * *$ & $-.17^{*}$ & -.11 & - \\
\hline$M$ & 3.52 & 5.93 & 0.33 & 3.51 & 1.61 & 13.46 \\
\hline$S D$ & 0.55 & 1.35 & 0.21 & 0.71 & 1.04 & 0.55 \\
\hline Alpha for scales & .84 & & & .87 & & \\
\hline
\end{tabular}

Note. $\mathrm{W}=$ wave, $\mathrm{GPA}=$ grade point average.

$* p<.05 . * * p<.01 . * * * p<.001$. 
Table 2. Descriptive Statistics by Gender, Race-ethnicity, and Intervention group (values in parentheses are SD)

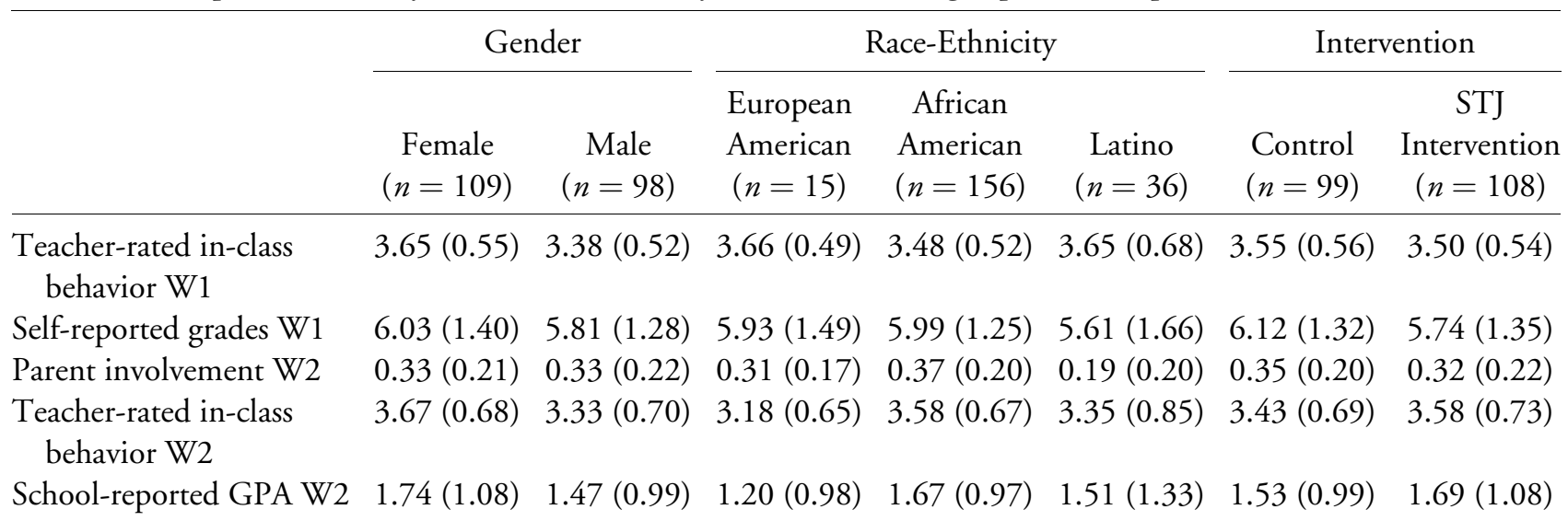

Note. STJ = School-to-Jobs; $\mathrm{W}=$ wave; GPA = Grade Point Average.

school?" Yes responses were coded as 1 and summed $(M=1.41, S D=1.18, \alpha=.54$, range $0-5)$. Low scores resulted in a skewed distribution, which was ameliorated via $\log$ transformation $(M=0.33$, $S D=0.21)$.

Participation in possible selves intervention. Youth assigned to intervention were compared to youth assigned to control. Two dummy variables (intervention group $=$ yes, no) were created following Oyserman et al. (2006). One dummy variable focused on youth's random assignment to the intervention versus control group. Analyses using this dummy variable (the ITT analyses) included all youth whether or not youth actually received the intervention. Analyses based on such an "ITT" sample preserve random assignment but are not a good test of intervention effects to the extent that some youth who did not receive the intervention are included in analyses of intervention effects. Given that our goal was to test whether participation in the intervention moderated the effect of low parent school involvement, the alternative is compliance analyses, which involves comparing those assigned to the intervention and receiving a meaningful dose of the intervention with those not assigned to the intervention but who are estimated to attend the intervention if assigned to it (Jo, 2002a, 2002b). What is meant by meaningful dose varies by intervention (see Gross et al., 2001). Although various cutoffs for noncompliance can be used, the literature suggests choosing the minimal level of meaningful dose from a theoretical perspective (e.g., Gross et al.). Consistent with the previous work on which the present study is based (Oyserman et al., 2006), attendance at five or more sessions (half) was considered the criteria of "reasonable dose"; all but $13.6 \%$ of participants met this criterion.

Use of compliance analyses to estimate effects for individuals who received a meaningful dose of an intervention is appropriate if two basic requirements are met: (a) assessed variables provide a useful and valid estimate of those likely to participate and (b) nonparticipators among those assigned to the experimental condition do not differ in outcomes from control condition youth (Jo, 2002a, 2002b). In the Oyserman et al. (2006) study, both requirements were met, as outlined below. Estimating the likelihood of participation among control group youth, had they been assigned to the experimental group, requires availability of baseline variables that account for the difference between ITT experimental group youth who were participators and those who were nonparticipators (Jo, 2002a). Participation was defined as coming to school for the intervention and nonparticipation as not being in school (e.g., being suspended, expelled, or absent). Demographic and preintervention variables significantly accounted for "participation" thus defined. As explained by Oyserman et al. (2006), most nonparticipating youth were suspended or expelled, and nonparticipating experimental youth differed significantly, at preintervention, from participating experimental youth, multivariate $F(13,250)=5.86, p<$ .001 : The nonparticipating youth were significantly older than participating youth $(38.9 \%$ vs. $15.4 \%$ were older than 14 years, the normative age for eighth grade), suggesting they had already been held back or experienced other educational setbacks. Prior to the intervention, nonparticipating youth self-reported worse academic outcomes and teachers 
rated their behavior more negatively. Because Oyserman et al. (2006) could estimate the likelihood of nonparticipation, they could identify and remove from the complier control group youth similar to nonparticipating experimental group youth.

To establish the validity of the compliance model, Oyserman et al. (2006) determined that the "exclusionary restriction" assumption was met, that the model was additive, and that covariate effects were constant (Jo, 2002b). First, they demonstrated that control youth and "noncompliant" intervention youth (those who went to fewer than five STJ sessions) did not differ on outcomes, for example, for spring of eighth grade outcomes, multivariate $F(11,136)=1.54, p=.13$. They then determined that intervention effects were additive and that covariate effects were constant (Jo, 2002b). Specifically, in the compliant sample, relationships between outcomes and compliance-related covariates (e.g., age) did not differ by conditions-multivariate $F(11$, $214)=1.40, p=.17$. And, in the ITT samplerelationships between outcomes and compliancerelated covariates did not differ between the compliant and the noncompliant samples. For example, for age, multivariate $F(11,250)=1.13, p=.34$. Because all tests of assumptions were met, the validity of the compliance model was supported so that we could use a second dummy variable to compare compliant intervention youth with control youth who would have been compliant if randomized to intervention.

Baseline performance controls. Baseline grades and in-class behavior were obtained in the 2006 study during the time which youth were in the fall of eighth grade and before the start of the intervention. Because school records were not available for the prior year, youth self-reported their average grades on a 9-point rating scale $(0=$ mostly $F$ 's, $8=$ mostly $A$ 's $)$ taking into account "plus" and "minus" grades. The average, $M=5.93$, reflects somewhat less than mostly $B$ 's. The in-class behavior control came from teacher rating using a 14-item, 5-point response scale $(1=$ never, 5 = always, adapted from Finn, Pannozzo, \& Voelkl, 1995) describing student initiative taking and disruptiveness (e.g., This student . . p pays attention in class, comes late to class [reverse-coded], completes homework and in-class assignments, loses, forgets, or misplaces materials [reverse-coded]).

Grades. School records of core grades (i.e., mathematics, science, history, English) were obtained for spring of ninth grade $(0.0=\mathrm{F}$ to $4.0=\mathrm{A})$. When school records suggested youth were no longer enrolled in school, research staff located youth at home to verify which school they currently attended. In the spring of ninth grade, 30 youth (13 in control and 17 in experimental groups) were both not on any district school roster and also reported to our staff that they did not attend any school. Schools dropped students from their roster if they were out of school for the full quarter. Dropping these students from analyses would have truncated the distribution so these students were assigned a grade point average of 0 and kept in the full sample in all analyses. It should be noted that the number of students not attending school did not significantly differ by condition, and results do not differ with these youth removed from analyses.

Teacher-rated in-class behavior. The same items used by fall eighth grade middle school teachers to rate student in-class behavior were rated by students' ninth grade high school teachers in the final weeks of the school year. As before, the items were averaged to create an adequately reliable scale.

\section{Results}

All regression analyses were conducted twice, once with the total randomized sample (ITT) and a second time with youth who attended half or more of sessions $(n=108)$ and a comparable sample of control youth ( $n=99$, compliance analyses). Analyses using the ITT and compliance samples yielded very similar patterns of results. Given journal space limits, only the compliance analyses are presented; ITT tables are available from the authors. Tables 3 and 4 present regression results examining the moderating role of the possible selves-based intervention on the effect of parent school involvement on grade point average (Table 3) and in-class behavior (Table 4).

Hierarchical multiple regressions were used to test the hypothesized moderating effect of participating in the possible selves-based intervention on the risk reducing impact of parent school involvement on academic outcomes. At block 1, the control variables age, gender, race-ethnicity, and baseline academic performance were entered. The race-ethnicity variable was dummy-coded with European Americans as the excluded group. African Americans showed more positive performance than European Americans, consistent with general trends in Detroit Public Schools. A significant main effect of 
Table 3. Predicting Grade Point Average from School-Report: Summary of Hierarchical Regression Analysis

\begin{tabular}{|c|c|c|c|c|c|c|c|c|c|c|c|c|}
\hline \multirow[b]{2}{*}{ Variable } & \multicolumn{3}{|c|}{ Model 1} & \multicolumn{3}{|c|}{ Model 2} & \multicolumn{3}{|c|}{ Model 3} & \multicolumn{3}{|c|}{ Model 4} \\
\hline & $B$ & $S E B$ & $\beta$ & $B$ & $S E B$ & $\beta$ & $B$ & $S E B$ & $\beta$ & $B$ & $S E(B)$ & $\beta$ \\
\hline Age & -.09 & 0.12 & -0.05 & -.08 & 0.12 & -0.04 & -.06 & 0.12 & -0.03 & -.04 & 0.12 & -0.02 \\
\hline Gender $($ male $=1)$ & -.06 & 0.13 & -0.03 & -.03 & 0.13 & -0.01 & -.03 & 0.13 & -0.01 & -.03 & 0.13 & -0.01 \\
\hline African American & .57 & 0.25 & $0.24^{*}$ & .59 & 0.25 & $0.24^{*}$ & .58 & 0.25 & $0.24^{*}$ & .53 & 0.25 & $0.22^{*}$ \\
\hline Latino & .39 & 0.39 & 0.14 & .34 & 0.28 & 0.12 & .38 & 0.29 & 0.14 & .25 & 0.29 & 0.09 \\
\hline $\begin{array}{l}\text { W1 self-reported } \\
\text { grades }\end{array}$ & .17 & 0.05 & $0.22 * *$ & .18 & 0.05 & $0.23^{* * *}$ & .18 & 0.05 & $0.23^{* * *}$ & .19 & 0.049 & $0.24 * * *$ \\
\hline $\begin{array}{l}\text { W1 teacher-rated } \\
\text { in-class behavior }\end{array}$ & .69 & 0.12 & $0.37 * * *$ & .71 & 0.12 & $0.38 * * *$ & .71 & 0.12 & $0.38 * * *$ & .37 & 0.12 & $0.36 * * *$ \\
\hline STJ intervention & & & & .30 & 0.13 & $0.14 *$ & .30 & 0.13 & $0.15 *$ & .79 & 0.25 & $0.38 * *$ \\
\hline W2 parent invol. & & & & & & & .34 & 0.32 & 0.07 & 1.10 & 0.46 & $0.23^{*}$ \\
\hline Parent Invol. $\times$ STJ & & & & & & & & & & -1.42 & 0.62 & $-0.31^{*}$ \\
\hline$R^{2}$ & & .24 & & & .26 & & & .2 & & & .29 & \\
\hline$F$ for change in $R^{2}$ & & 10.66 & $5 * * *$ & & 5.25 & $5 *$ & & 1.1 & & & $5.24^{\prime}$ & \\
\hline
\end{tabular}

Note. Parent invol. $=$ parent school involvement; $\mathrm{STJ}=$ School-to-Jobs; $\mathrm{W}=$ wave.

$* p<.05 . * * p<.01 . * * * p<.001$.

intervention participation on 2-year outcomes for both school-reported grade point average, $\Delta F(1$, $199)=5.25, p=.02$, and teacher-rated behavior, $\Delta F(1,199)=5.75, p=.02$, was found at block 2 . At block 3, parent school involvement and at block 4 the parent school involvement by intervention participation two-way interaction was entered.

As predicted, the effect of parent school involvement was moderated by intervention participation, for both grade point average, $\Delta F(1,197)=5.24$, $p=.02$, and teacher-rated behavior, $\Delta F(1,197)=$ 7.35, $p=.007$ (see Tables 3 and 4). To interpret these results, simple slopes were examined following the procedures suggested by Aiken and West (1991). As depicted graphically in Figures 1 and 2, the influence of parent school involvement differs dramatically for control group compared to intervention group youth. For control group youth, parent school

Table 4. Predicting Teacher-Rated In-Class Behavior: Summary of Hierarchical Regression Analysis

\begin{tabular}{|c|c|c|c|c|c|c|c|c|c|c|c|c|}
\hline \multirow[b]{2}{*}{ Variable } & \multicolumn{3}{|c|}{ Model 1} & \multicolumn{3}{|c|}{ Model 2} & \multicolumn{3}{|c|}{ Model 3} & \multicolumn{3}{|c|}{ Model 4} \\
\hline & $B$ & $S E B$ & $\beta$ & $B$ & $S E B$ & $\beta$ & $B$ & $S E B$ & $\beta$ & $B$ & $S E(B)$ & $\beta$ \\
\hline Age & -.16 & 0.09 & -.12 & -.16 & 0.08 & -0.12 & -.15 & 0.09 & -0.11 & -.13 & 0.08 & -0.10 \\
\hline Gender $($ male $=1)$ & -.26 & 0.09 & $-.18 * *$ & -.23 & 0.09 & $-0.16^{*}$ & -.23 & 0.09 & $-0.16^{*}$ & -.23 & 0.09 & $-0.16^{*}$ \\
\hline African American & .45 & 0.27 & $.27^{*}$ & .46 & 0.17 & $0.28 * *$ & .46 & 0.17 & $0.28 *$ & .41 & 0.17 & $0.25^{*}$ \\
\hline Latino & .23 & 0.20 & .12 & .20 & 0.20 & 0.10 & .21 & 0.20 & $0.11^{*}$ & .10 & 0.20 & 0.05 \\
\hline $\begin{array}{l}\text { Self-reported } \\
\text { grades (W1) }\end{array}$ & .06 & 0.04 & .12 & .07 & 0.04 & $0.14^{*}$ & .07 & 0.04 & $0.14 *$ & .08 & 0.03 & $0.15^{*}$ \\
\hline $\begin{array}{l}\text { Teacher-rated in-class } \\
\text { behavior (W1) }\end{array}$ & .34 & 0.09 & $.26 * * *$ & .35 & 0.09 & $0.27 * * *$ & .35 & 0.09 & $0.27 * * *$ & .32 & 0.09 & $0.25^{* * *}$ \\
\hline Intervention & & & & .22 & 0.09 & $0.15^{*}$ & .22 & 0.09 & $0.15^{*}$ & .62 & 0.17 & $0.44^{* * *}$ \\
\hline Parent involvement & & & & & & & .08 & 0.22 & 0.03 & .71 & 0.32 & $0.21 *$ \\
\hline $\begin{array}{l}\text { Parent Involvement } \times \\
\text { Intervention }\end{array}$ & & & & & & & & & & -1.17 & 0.43 & $-0.37^{* *}$ \\
\hline$R^{2}$ & & .21 & & & .2 & & & .2 & & & .26 & \\
\hline$F$ for change in $R^{2}$ & & $8.60^{\circ}$ & & & 5.7 & & & .1 & & & 7.35 & \\
\hline
\end{tabular}

${ }^{*} p<.05 .{ }^{* *} p<.01 .{ }^{* * *} p<.001$. 


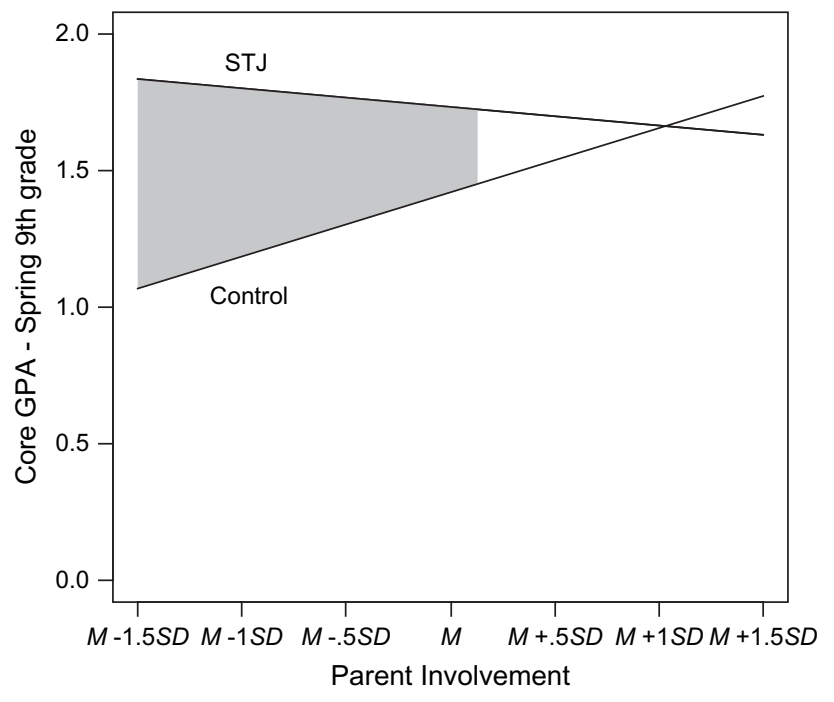

Figure 1. School-to-Jobs Improves Grades for Students With Low Parent School Involvement.

Note. The shaded area indicates all points at which intervention is significantly different from control at $p<.05$ (two tailed).

involvement had a positive effect on both grade point average $(\beta=1.10, p=.02$, Figure 1$)$, and teacherrated behavior $(\beta=0.71, p=.03$, Figure 2$)$. For students in the intervention, however, parent school involvement did not influence either grade point average $(\beta=-0.32, p>.40)$ or teacher-rated behavior $(\beta=-0.46, p>.1)$, indicating that the intervention helped youth compensate for low parent school involvement.

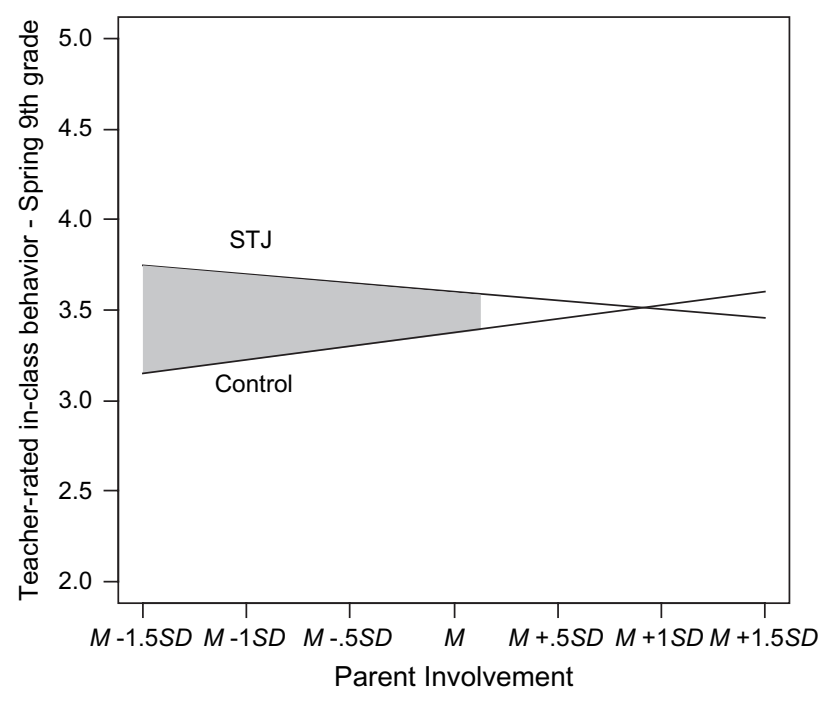

Figure 2. School-to-Jobs Improves Teacher-Rated Class Behavior for Students With Low Parent School Involvement.

Note. The shaded area indicates all points at which intervention is significantly different from control at $p<.05$ (two tailed).
The significant region of treatment differences (Bauer \& Curran, 2005) was calculated to determine the maximal level of parent school involvement up to which the intervention improved outcomes. Students in the intervention group had significantly higher grades (Figure 1) and better teacher-rated behavior (Figure 2) than those in the control group when parent school involvement was low to moderate, that is, when parent school involvement was less than the mean involvement, when parent school involvement was at the average level, and when parent school involvement was higher than the average level by up to two tenths of a standard deviation above mean parental school involvement $(M+0.2 S D)$. This can also be understood in terms of the percentage of the current sample that would benefit from the intervention because of low parent school involvement. When the significant region of treatment difference is translated to a percentage, we found that $64 \%$ of the present sample had parent school involvement low enough to benefit from the intervention.

\section{Discussion and Implications for Policy and Practice}

Parent school involvement is consistently associated with positive school outcomes through middle and high school (Woolley \& Bowen, 2007; Woolley \& Grogan-Kaylor, 2006). Because this research simply demonstrates associations (often at single points in time), it cannot clarify how or why parental school involvement matters for middle and high school aged children. We theorize that highly schoolinvolved parents provide youth with a sense that doing well in school is possible for them and therefore is worth investing in and that becoming offtrack can be avoided via engagement with school. We build on this framework by testing whether an intervention aimed at enhancing youths' possible selves moderates the effects of low parent school involvement on academic outcomes as operationalized by grade point average and on-task in-class behavior.

In the control group, we found that low parent school involvement was associated with reduced academic success (e.g., lower grades, worse in-class behavior), consistent with previous research (e.g., Grolnick \& Slowiaczek, 1994; Miedel \& Reynolds, 1999; Woolley \& Bowen, 2007; Woolley \& 
Grogan-Kaylor, 2006). This was not the case for youth in the intervention group. In the intervention group, low parent school involvement did not have a negative effect on academic success. Although the direct causal influence of parent school involvement on youths' possible selves could not be tested with the current data, as we only have one post-only parent involvement data point, our interpretation of these results is that the negative effects of low parent school involvement can be ameliorated by interventions aimed at enhancing youth's possible selves.

Our interpretation is both based on prior research and drawn from the current results. Oyserman et al. (2006) reported that the intervention changed youths' possible selves in two ways. School-focused possible selves became more salient after the intervention among youth randomly assigned to the intervention compared to control youth. The intervention also had significant effects on the salience of possible selves focused on avoiding becoming offtrack (e.g., using drugs, becoming pregnant). Intervention youths became more concerned about avoiding these possible selves compared to control youths. Moreover, these changes in school-focused and feared offtrack possible selves mediated the intervention's direct effects on academic outcomes (Oyserman et al., 2006). Given that the current results show that the negative effect of low parent school involvement on school grades and teacherreported in-class behavior were eliminated for intervention youth, current results lend support to the hypothesis that the effect of parent school involvement depends on whether youth participated in the possible selves-focused intervention.

A limitation of the current study is that parent school involvement data were collected at only one point in time, making a direct test of the influence of parent school involvement on creation and maintenance of possible selves impossible. Also, other potential pathways through which parent school involvement may matter were not assessed and our measure was brief and focused on behaviors not related to involvement as a result of child behavior problems. Thus, we were not able to evaluate the full extent to which the intervention helped youth compensate for parent school involvement, only to document that the intervention moderated the effects of parent school involvement on the measured outcome variables. Our brief measure was marginally reliable, and there are likely to be other benefits of parent school involvement that interventions directly targeting youth cannot provide. The present research does not obviate the need for support to parents so that they can have the time and resources to be involved with their children's school. Finally, we could not conduct more nuanced analyses of potential differential effectiveness relating to family income, education, and other indicators of economic status because we did not collect data on family characteristics. Instead, we assumed that families were mostly low income, because we had information about rates of free lunches provided at the schools and census track information about neighborhood poverty levels. We demonstrate effects across potentially heterogeneous family education, income, and other status characteristics.

Despite these limitations, results suggest both that evaluating intervention effects is a useful venue for future process-oriented research on parent school involvement and that school-based universal interventions may provide a viable resource for children whose parents face barriers to involvement with school. One parent-focused alternative is to examine other things parents can do to help children view school success as a possible self and articulate school as a venue for reducing chances of becoming offtrack. Similarly, school-based possible self-focused interventions can bolster youth's school-focused efforts even in neighborhoods without exceptional social capital. Interventions such as the one examined in the current study that focus children's attention on school as a path to success and as a way to avoid failures may engage children in ways that are congruent with what may occur when parent school involvement is high. For example, when parents are involved in schools, children may come to see school as a safe and valued place where one would choose to spend time. For children whose parents are low in school involvement, creating a sense that school success is possibly self-defining should also increase willingness to spend time in school, reducing risk of skipping school, and increasing chances of participation in in-school activities. Students who participate are likely to form more positive connections not only with school as an idea about the future but also with specific teachers, again paralleling potential consequences of high parent school involvement. In these and other ways, interventions focused on possible selves can moderate some negative effects of low parent school involvement. Because school success is critical to future life tasks, these interventions are worth our attention. 


\section{References}

Aiken, L. S., \& West, S. G. (1991). Multiple regression: Testing and interpreting interactions. Newbury Park, CA: Sage.

Anderman, E. M., Anderman, L. H., \& Griesinger, T. (1999). The relation of present and possible academic selves during early adolescence to grade point average and achievement goals. Elementary School Journal, $100,3-17$.

Baker, D. P., \& Stevenson, D. L. (1986). Mothers' strategies for children's school achievement: Managing the transition to high school. Sociology of Education, 59, 156-166.

Bauer, D. J., \& Curran, P. J. (2005). Probing interactions in fixed and multilevel regression: Inferential and graphical techniques. Multivariate Behavioral Research, 40,373-400.

Bishaw, A. (2005). Areas with concentrated poverty: 1999 Census 2000 Special Reports. Retrieved March 6, 2007, from http://www.census.gov/ $\mathrm{prod} / 2005 \mathrm{pubs} / \mathrm{censr}-16 . \mathrm{pdf}$

Bulcroft, R. A., Carmody, D. C., \& Bulcroft, K. A. (1998). Family structure and patterns of independence giving to adolescents. Journal of Family Issues, 19, 404-435.

Connell, J. P., Spencer, M. B., \& Aber, J. L. (1994). Educational risk and resilience in African-American youth: Context, self, action, and outcomes in school. Child Development, 65, 493-506.

Cross, S., \& Markus, H. (1991). Possible selves across the life span. Human Development, 34, 230-255.

Cross, S., \& Markus, H. (1994). Self-schemas, possible selves, and competent performance. Journal of Educational Psychology, 86, 423-438.

Eccles, J. S., \& Harold, R. D. (1996). Family involvement in children's and adolescents' schooling. In A. Booth, \& J. F. Dunn (Eds.), Family-school links: How do they affect educational outcomes? (pp. 3-34). Mahwah, NJ: Lawrence Erlbaum.

Finn, J., Pannozzo, G., \& Voelkl, K. E. (1995). Disruptive and inattentivewithdrawn behavior and achievement among fourth graders. Elementary School Journal, 95, 421-434.

Grolnick, W. S., \& Slowiaczek, M. L. (1994). Parents' involvement in children's schooling: A multidimensional conceptualization and motivational model. Child Development, 65, 237-252.

Gross, D., Julion, W., \& Fogg, L. (2001). What motivates participation and dropout among low-income urban families of color in a prevention intervention? Family Relations, 50, 246-254.

Hrabowski, F. A., Maton, K., \& Greif, G. (1998). Beating the odds: Raising academically successful African American males. New York: Oxford University Press.

Hill, N. E. (2001). Parenting and academic socialization as they relate to school readiness: The roles of ethnicity and family income. Journal of Educational Psychology, 93, 686-697.

Hill, N. E., Castellino, D. R., Lansford, J. E., Nowlin, P., Dodge, K. A., \& Bates, J. E. (2004). Parent academic involvement as related to school behavior, achievement, and aspirations: Demographic variations across adolescence. Child Development, 75, 1491-1509.

Hill, N. E., \& Taylor, L. C. (2004). Parent school involvement and children's academic achievement: Pragmatics and issues. Current Directions in Psychological Science, 13, 161-164.

Ialongo, N., Werthamer, L., Kellam, S., Brown, C., Wang, S., \& Lin, Y. (1999). Proximal impact of two first-grade preventive interventions on the early risk behaviors for later substance abuse, depression, and antisocial behavior. American Journal of Community Psychology, 27, 599-642.

Jo, B. (2002a). Estimation of intervention effects with noncompliance: Alternative model specifications. Journal of Educational and Behavioral Statistics, 27, 385-409.

Jo, B. (2002b). Statistical power in randomized intervention studies with noncompliance. Psychological Methods, 7, 178-193.

Knox, M., Funk, J., Elliot, R., \& Bush, E. G. (1998). Adolescents' possible-selves and their relationship to global self-esteem. Sex Roles, 39, 61-80.

Lareau, A. (1996). Assessing parent involvement in schooling: A critical analysis. In A. Booth, \& J. F. Dunn (Eds.), Family-school links: How do they affect educational outcomes? (pp. 57-64). Mahwah, NJ: Erlbaum.
Little, R., \& Rubin, D. (2002). Statistical analysis with missing data (2nd ed.). New York: Wiley.

Little, R., \& Yau, L. (1998). Statistical techniques for analyzing data from prevention trials: Treatment of no-shows using Rubin's causal model. Psychological Methods, 3, 147-159.

Machida, S., Taylor, A., \& Kim, J. (2002). The role of maternal beliefs in predicting home learning activities in Head Start families. Family Relations, 51, 176-184.

Markus, H., \& Nurius, P. (1986). Possible selves. American Psychologist, $41,954-969$

Marschall, M. (2006). Parent involvement and educational outcomes for Latino students. Review of Policy Research, 23, 1053-1076.

McCabe, K., \& Barnett, D. (2000). First comes work, then comes marriage: Future orientation among African American young adolescents. Family Relations, 49, 63-70.

Miedel, W. T., \& Reynolds, A. J. (1999). Parent involvement in early intervention for disadvantaged children: Does it matter? Journal of School Psychology, 37, 370-402.

Morrison, F., Bachman, H., \& Connor, C. (2005). Improving literacy in America: Guidelines from research. New Haven, CT: Yale University Press.

North Central Regional Educational Laboratory. (1995). Literature review of school-family partnerships. Retrieved October 1, 2005, from http:// www.ncrel.org/sdrs/pidata/pi0ltrev.htm

Orfield, G. (2004). Dropouts in America: Confronting the graduation rate crisis. Cambridge, MA: Harvard Education Press.

Oyserman, D. (2007). Social identity and self-regulation. In A. Kruglanski, \& E. T. Higgins (Eds.), Handbook of social psychology: Basic principles (2nd ed., pp. 432-453). New York: Guilford Press.

Oyserman, D. (in press). Adolescent pathways: An identity-based motivation program for school success. New York: Oxford University Press.

Oyserman, D., Bybee, D., \& Terry, K. (2006). Possible selves and academic outcomes: How and when possible selves impel action. Journal of Personality and Social Psychology, 91, 188-204.

Oyserman, D., Bybee, D., Terry, K., \& Hart-Johnson, T. (2004). Possible selves as roadmaps. Journal of Research in Personality, 38, 130-149.

Oyserman, D., \& Fryberg, S. A. (2006). The possible selves of diverse adolescents: Content and function across gender, race and national origin. In C. Dunkel, \& J. Kerpelman (Eds.), Possible selves: Theory, research, and applications (pp. 17-39). Huntington, NY: Nova.

Oyserman, D., Gant, L., \& Ager, J. (1995). A socially contextualized model of African American identity: Possible selves and school persistence. Journal of Personality and Social Psychology, 69, 1216-1232.

Oyserman, D., \& Markus, H. (1990a). Possible-selves and delinquency. Journal of Personality and Social Psychology, 59, 112-125.

Oyserman, D., \& Markus, H. (1990b). Possible-selves in balance: Implications for delinquency. Journal of Social Issues, 46, 141-157.

Oyserman, D., \& Saltz, E. (1993). Competence, delinquency, and attempts to attain possible-selves. Journal of Personality and Social Psychology, 65, $360-374$.

Oyserman, D., Terry, K., \& Bybee, D. (2002). A possible selves intervention to enhance school involvement. Journal of Adolescence, 25, 313326.

Reynolds, A. J. (1991). Comparing measures of parent involvement and their effects on academic achievement. Early Childhood Research Quarterly, 7, 441-462.

Steinberg, L., Lamborn, S. D., Dornbusch, S. M., \& Darling, N. (1992). Impact of parenting practices on adolescent achievement: Authoritative parenting, school involvement, and encouragement to succeed. Child Development, 63, 1266-1281.

Woolley, M., \& Bowen, G. (2007). In the context of risk: Supportive adults and the school engagement of middle school students. Family Relations, $56,92-104$.

Woolley, M., \& Grogan-Kaylor, A. (2006). Protective family factors in the context of neighborhood: Promoting positive school outcomes. Family Relations, 55, 93-104.

Yowell, C. M. (2000). Possible-selves and future orientation: Examining hopes and fears of Latino boys and girls. Journal of Early Adolescence, $20,245-280$.

Yowell, C. M. (2002). Dreams of the future: The pursuit of education and career possible-selves among ninth grade Latino youth. Applied Developmental Science, 6, 62-72. 